\title{
Growth in Malaysia's Export Food Market: A Shift-Share Analysis
}

\author{
Emmy Farha Alias ${ }^{1}$, Alias Radam ${ }^{2}$, Yeong Pei Fen ${ }^{2}$, Mohd Rusli Yacob ${ }^{3} \&$ Md. Ferdous Alam ${ }^{4}$ \\ ${ }^{1}$ Institute of Agricultural and Food Policy Studies, Universiti Putra Malaysia, Selangor, Malaysia \\ ${ }^{2}$ Faculty of Economics and Management, Universiti Putra Malaysia, Selangor, Malaysia \\ ${ }^{3}$ Faculty of Environmental Studies, Universiti Putra Malaysia, Selangor, Malaysia \\ ${ }^{4}$ Faculty of Arts and Social Sciences, American International University-Bangladesh, Bangladesh \\ Correspondence: Emmy Farha Alias, Institute of Agricultural and Food Policy Studies, Universiti Putra Malaysia, \\ 43400 UPM Serdang, Selangor, Malaysia. Tel: 60-3-8947-1073. E-mail: emmyfarha@gmail.com
}

Received: July 7, 2013 Accepted: December 12, 2013 Online Published: January 27, 2014

doi:10.5539/ass.v10n3p26 URL: http://dx.doi.org/10.5539/ass.v10n3p26

\begin{abstract}
Agriculture sector plays an important role in the Malaysian economy. Malaysia experiences deficit in food balance of trade but some of the agricultural products such as palm oil, fisheries etc. have competitive advantage. This paper aims to examine Malaysia's export food market growth between 1996 and 2009 using shift-share analysis. Findings show that the major export commodities from Malaysia are animal or vegetable fats and oils and their cleavage products; prepared edible fats; animal or vegetable waxes (HS 15) during the said period. The increasing growth rate of Malaysia's exports is found in the newly industrialized countries such as China, Iran, India and Ukraine due to their increasing demand for edible oil. However, influences of the trading agreements between these countries also cannot be denied.
\end{abstract}

Keywords: shift-share analysis, food market, palm oil, edible oil

\section{Introduction}

The Malaysian economy had experienced a rapid growth. The agricultural sector had played an important role in the rapid economic growth. The main food export of Malaysia is the palm oil. It is the cheapest commodity vegetable oil enabling the developing countries to afford to consume. Due to the income growth of those countries, the demand is rapidly increasing. As the world leading exporter of palm oil, the palm oil production is very important to develop the country. Malaysia experiences producing, trading and financing palm oil and export $88 \%$ of the total palm oil to other countries. Nowadays, China and India are the largest markets to import palm oil from Malaysia. The large population in these most concentrated population regions made the demand for edible oil increased rapidly. China increased up to 5499000 tonne by 2007 from 1373200 tonne in 1998 (Arif Simeh et al., 2009). India is the second largest vegetable oil market in the world accounting for $55 \%$ of the total imports in India (Arif Simeh et al., 2009).

About $33 \%$ of the world agricultural exports were from the developing countries (Wiig \& Kolstad, 2005). However, its world merchandise exports were about 25\% (Wiig \& Kolstad, 2005). A lot of agreements to remove the barriers of trading have been established. The world trend to eliminate all the barriers in agricultural products was implemented by WTO. WTO members have to improve the ease of market access, reduce the export subsidies and reduce in trade-distorting domestic support to expand the opportunities for their members to improve the comparative advantage (Wiig \& Kolstad, 2005). However, the barriers are also found in many countries to protect their nation's industry, especially in the developing countries which may not really fully take advantage from the new opportunities since they all tend to protect their own industry in order to maintain the competitive advantage. Although they understand the benefits for the free trade, the local producers still need a long period to gain competency to avoid losing their market share. To protect the local producers, the government imposed new non-tariff barriers to replace the traditional tariff and quota.

In developing countries, most of the populations depend on their agricultural commodities in terms of exports or employment for livelihood. Due to their poor competitiveness and lack of comparative advantage in competing world, they lost ground in international trade. The developed countries' tariffs, subsidies and other trade policy instruments had weakened the market share of developing countries. The developed countries also set up some 
regulations to ensure the quality of food which turns out to be a barrier to the exporting countries. For example, Sanitary and Phytosanitary (SPS) regulations imposed by the developed world reduced the export opportunities of developing countries (Wiig \& Kolstad, 2005). Developed countries provided technical assistance to developing countries in meeting the SPS requirements. This regulation makes the producers of the developing countries bear the SPS-related technical assistance cost since the countries do not have resources to upgrade the sanitary capacity.

Over the past decades, Malaysia's food export and food import patterns had changed notably. Singapore which is the nearest country to Malaysia was posted as a major negative net shifts market of the total Malaysia's exports. Before this, Singapore was the major export market for Malaysia. China which has the highest population in the world replaced the position as the largest positive net shifts market of the Malaysia's total exports. China was recorded as the fastest growing country in the world that provided a great opportunity for many of the countries to export their commodities due to the increasing nature of demands in China. Besides, Malaysia tends to export more commodities to ASEAN.

The changes of the exports trend were mainly due to the AFTA scheme that emphasized the reducing of the duties among the ASEAN countries including of agricultural food products (Stanton, Emms \& Sia, 2006). The non-tariff barriers had been removed gradually to trade within ASEAN countries. AFTA also made the South East Asia's trade flows smaller in investment flows in the past ten years (Stanton, Emms \& Sia, 2006). Among the South East Asian countries, China was the only market that experienced the positive net shifts, while the trade volume of Hong Kong, Japan, South Korea and Taiwan experienced negative net shifts of Malaysia's total exports. Therefore, this study is conducted to examine the performance of Malaysian food exports from 1996 to 2009 using the shift-share analysis

\section{Literature Review}

The early application of the shift-share analysis was an argument in the past. Edgar Hoover claimed that the method was first used by Creamer in 1942 in the United State in manufacturing industry between 1929 and 1937 (Hoover, 1971). Armstrong and Taylor claimed that the shift-share technique was first used by Jones in 1940 (Armstrong \& Taylor, 1978). However, there is not much information about Jones's works that based on the shift-share technique. Stevens and Moore cited Dunn is the originator who first made use of the current standard three components approach (Stevens \& Moore, 1980).

Kian and Fot (1999) used the shift-share methodology to study the growth of export markets in Singapore during 1991 to 1996 . With the technique, they found that Malaysia was the largest positive net shift export market to Singapore. Besides, it also showed that Singapore had to diversify its export markets. The regional economy did not influence its export growth. However, it boosted the exports in the countries which was heavily invested by Singapore.

Wilson et al. (2005) examined the export performance of China in electronics compared to the east Asian NIEs exporting to the USA, European Union and Japan between 1988 and 2001 with the dynamic shift-share analysis. The findings showed that China had emerged as a serious competitor in electronics export market, but it was still not a dominant one as China still could not gain in the high-end exports in developed markets. So, the increase in market share was suggested to the overall growth. However, the rapid growth since early 1990s strengthens the export growth rather than a favourable industry mix. If China can sustain the exports growth, China's overall competitiveness can be expected to improve in the future.

Wali studied the industrial development potential of Malaysia with shift-share approach in 2009. The paper discussed the unique industrial mix of the East Coast Economic Region (ECER) of Malaysia (Provinces of Kelantan, Terengganu, Pahang and Northern Johor) for economic development. Wali decomposed the growth of income or employment in East Coast Economic Region of Malaysia and demonstrated the findings in a defined period into the National Growth, Industrial Mix and Competitive Share components.

Castaldi (2008) examined the relative weight of manufacturing and services in European countries, United State and Japan. The role of the structural change process on the growth rate for last three decades was assessed. The findings showed the employment shifted to service sector for labour productivity growth with the highest contribution of networks services to the productivity growth. However, the scale intensive and science-based industries still remain fundamental sources of technologies and knowledge in the whole system.

\section{Methodology}

Shift-share technique methodology is extensively used in regional economic analysis to examine the differences among regional and national growth rates such as export market growth, industrial structure, employment 
changes as well as labour productivity. It provides very simple decomposition to some meaningful economic interpretation for the comparative dimension to trade performance. It can be used to assess the implications of structural developments over time on a country's international competitive position. It is an analysis which requires doing the comparison rather than observing the absolute changes or percentage changes in exports of a selected group of reference economies.

Shift-share analysis deals with the economic growth over time, so a time frame is required for the analysis. For this study, the time period chosen is from year 1996 to 2009. In this paper, the nominal data from Global Trade Atlas are used. It involves 24 commodities from HS01 to HS24. The description of the commodities is shown in Table 1. The paper first examines the total exports. After that, it focuses on Malaysia's top five positive and negative net shift markets in order to keep the analysis manageable. It is expected that a better perspective of Malaysia's trade patterns will be portrayed by making use of shift-share analysis.

Table 1. Descriptions of the HS codes

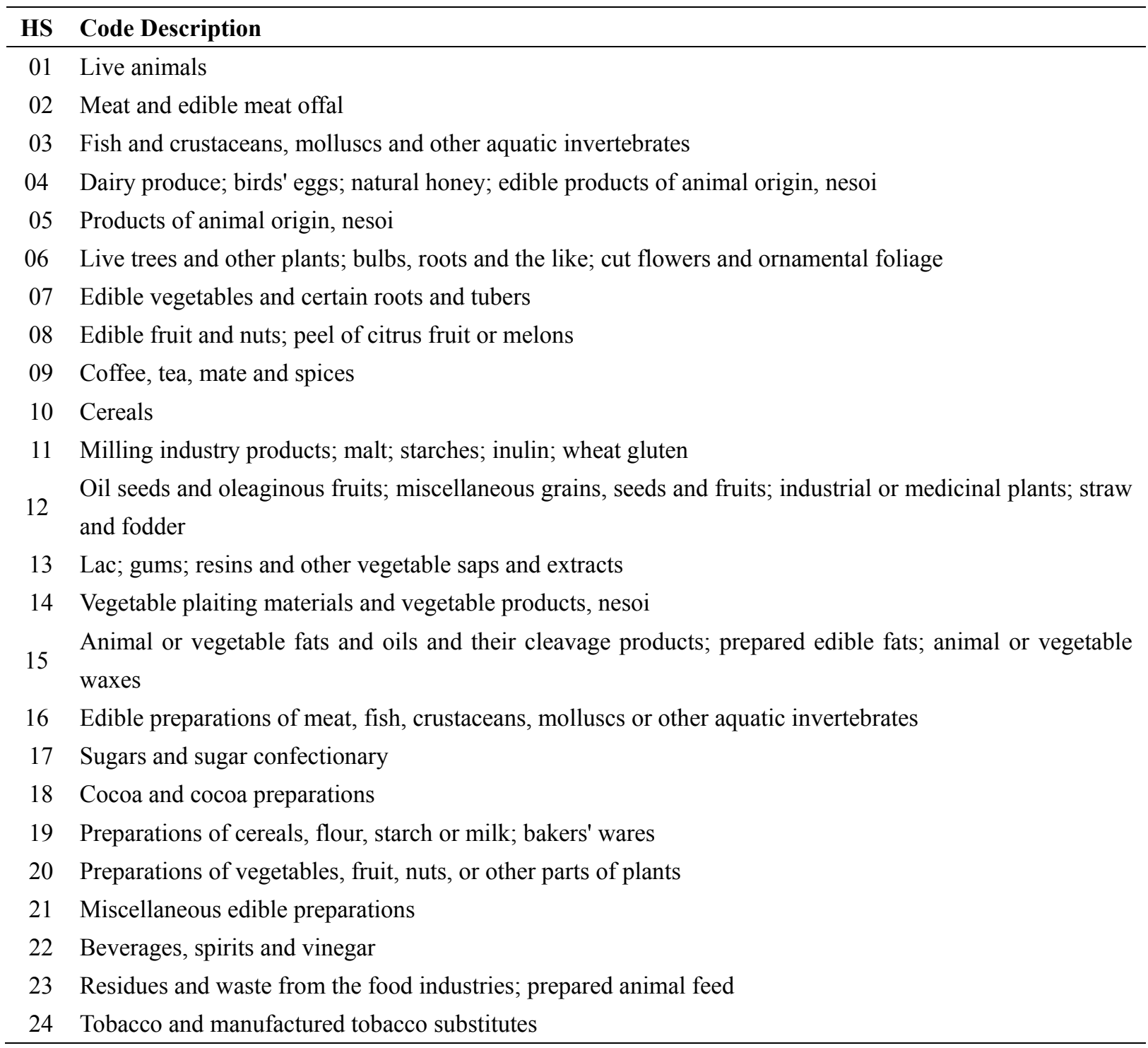

\subsection{Net Shifts in Export Market}

Shift-share analysis in the study of Malaysia's export market growth can be measured with the total changes in gains or losses of the export markets relative to the overall export growth is called share effect or overall growth. The net shifts in exports measure the export market performance. A positive net shift refers to an enhancement in competitiveness for the country relative to the overall growth while a negative net shift refers to a negative value 
which indicates a weakening in competitiveness. Net shifts in export markets can be ascribed to three components which are industry mix effect, regional effect and interaction effect.

This paper has made use of the shift-share analysis framework by Kian and Fot (1999) as shown in Figure 1.

$$
\begin{gathered}
\sum_{i} X_{t-1}^{i j} \cdot\left\{\left(\frac{X_{t}^{i}}{X_{t-1}^{i}}\right)-\left(\frac{X_{t}}{X_{t-1}}\right)\right\} \\
\text { (Industry Mix Effect) } \\
+ \\
\sum_{i} X_{t-1}^{j} \cdot \frac{X_{t-1}^{i}}{X_{t-1}} \cdot\left\{\left(\frac{X_{t}^{i j}}{X_{t-1}^{i j}}\right)-\left(\frac{X_{t}^{i}}{X_{t-1}^{i}}\right)\right\} \\
\quad \text { Regional Effect) } \\
+ \\
\sum_{i}\left\{X_{t-1}^{i j}-X_{t-1}^{j} \cdot \frac{X_{t-1}^{i}}{X_{t-1}}\right\} \cdot\left\{\left(\frac{X_{i j}^{i j}}{X_{t-1}^{i j}}\right)-\left(\frac{X_{t}^{i}}{X_{t-1}^{i}}\right)\right\} \\
\quad \text { (Interaction Effect) } \\
X_{t=\sum_{j}^{i} X_{i}^{i j}=} \text { Exports of commodity } i \text { to all markets; } \\
X_{t}^{j}=\sum_{i} X_{t}^{i j}=\text { Exports of all commodities to market } j ; \\
X_{t}=\sum_{i} \sum_{j} X_{i}^{i j}=\text { Total exports }
\end{gathered}
$$

Figure 1. Shift-share analysis research framework

\subsection{Industry Mix Effect}

Industry mix effect captures the segment of the export differential due to difference between the composition of exports to a market and the composition of Malaysia's total exports. It is very important to determine export differential in competing economy's structure. A positive effect will be occurred if the share of the total exports to a market in fast-growing commodities is better than the share of the Malaysia's overall exports in these commodities. Conversely, a negative effect will be occurred if the exports to a market are highly concentred in slow-growing commodities across the composition of Malaysia's total exports.

\subsection{Regional Effect}

Regional effect shows the effect of differential growth of various export commodities between the export growth rates in Malaysia compared to other markets. It captures contribution of the particular drive of that sector in the country compared to the sector growth. However, the merge of exports to two markets perhaps similar, so the difference growth rates of individual commodity exports between the markets can contribute to a net shift in export market shares. The regional effect is positive, if the exports growth rates of a variety of commodities to a market are higher than country's overall export growth in these commodities. The negative regional effect occurs when the condition is vice versa.

\subsection{Interaction Effect}

Interaction effect measures net shift due to the difference in combination of the industry mix effect and regional effect to the various markets which interacts with the difference growth of commodity exports to these markets. A positive effect occurs if the exports to a market are either industry mix effect intense in those commodities faster than the average overall export growth. A positive effect may also occur if regional effect is not concentrated with slower than the average overall export growth. 


\section{Results and Discussion}

\subsection{Trends in Malaysia's Export Markets Growth}

Figure 1 and 2 show the Malaysia's total exports during 1997 to 2009. These figures clearly show that HS 15 (animal or vegetable fats and oils and their cleavage products; prepared edible fats; animal or vegetable waxes) has the largest share of export volumes accounting for $68 \%$ and $72 \%$ in 1997 and 2009, respectively. According to Edmund (2007), this is because of the consideration of Malaysia as a leading export country in the world for the edible oil. Besides, vegetable oil also gets a higher demand from China since they are shifted to the higher income society (Malaysian-German Chamber of Commerce and Industry, 2010).

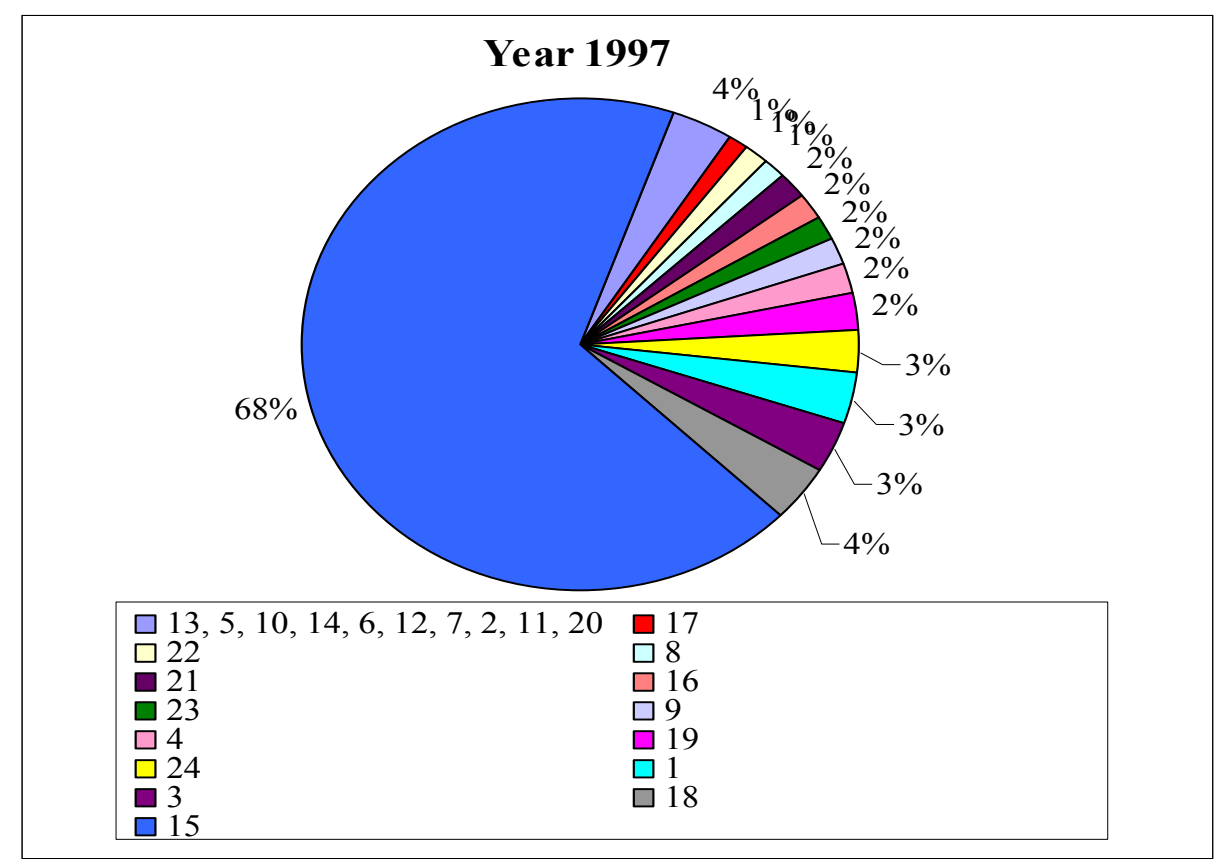

Figure 1. Malaysia's total exports by commodity, 1997

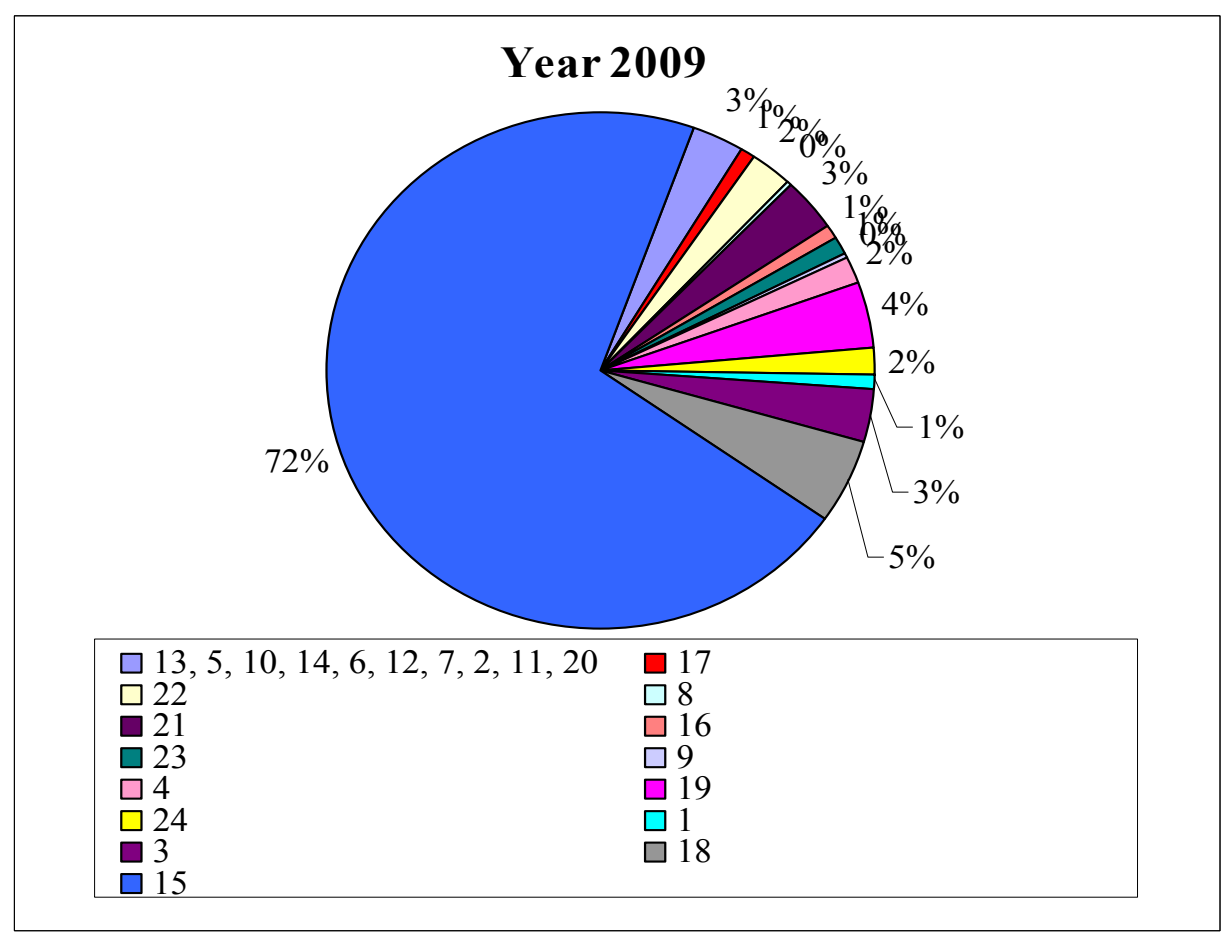

Figure 2. Malaysia's total exports by commodity, 2009 
An increasing share of export for HS 18 (cocoa and cocoa preparations) from $4 \%$ in 1997 to $5 \%$ in 2009 was recorded. This performance has been achieved due to the production of high quality of cocoa beans in 2009 using controlled fermentation and gives a higher price (New Sabah Times, 2010). The HS 03 (fish and crustaceans, molluscs and other aquatic invertebrates), HS 01 (live animals) and HS 24 (tobacco and manufactured tobacco substitutes) share a same percentage of export shares of $3 \%$ in 1997. However in 2009, only HS 03 maintained the same percentage of export share. HS 24 could not maintain the share due to introduction for alternative commercial crops to replace the tobacco by the Malaysian government (Ahmad Ibrahim, 2008).

The Agricultural Agreement and AFTA gave an impact for HS 09 (coffee, tea, mate and spices) where the export share is observed to have decreased from $2 \%$ in 1997 to $0 \%$ in 2009 . The agreements reduced the tariffs up to $34 \%$ and the countries with comparative advantage in the product are benefited by exporting it.

\subsection{Malaysia's Key Export Markets}

Figure 3 and 4 show the top ten food exports destination in 1997 and 2009. Singapore was the largest key export market with $24 \%$ export share and China was the second in position with $15 \%$ export share in 1997 . However, in 2009, China became the largest key export markets receiving 29\% export from Malaysia while Singapore became the second in position with $14 \%$ share. The increasing trend for the food exports to China was mainly because of the stunning economic growth that led to increase the demands for the wide range of industries in China. However, Singapore depends solely on the food import from Malaysia due to the limitation to produce the agricultural products such as land.

Ukraine is one of the Malaysia's food exports destinations in 2009 which accounted for $4 \%$ of the total Malaysia's food export. Ukraine is the world's biggest producer for the sunflower seed crops in edible processing industry. Due to the importance of the industry, palm oil is an alternative to maintain and reduce their processing cost (www.foodnavigator.com, 2004).

United States obtained 5\% of the total exports in 1997 and it increased to $11 \%$ in 2009. The growth in the total export took place due to the Free Trade Agreement (FTA) between Malaysia and United States. Most of the agricultural commodities experienced an increasing trend in the Malaysia's total exports to United States.

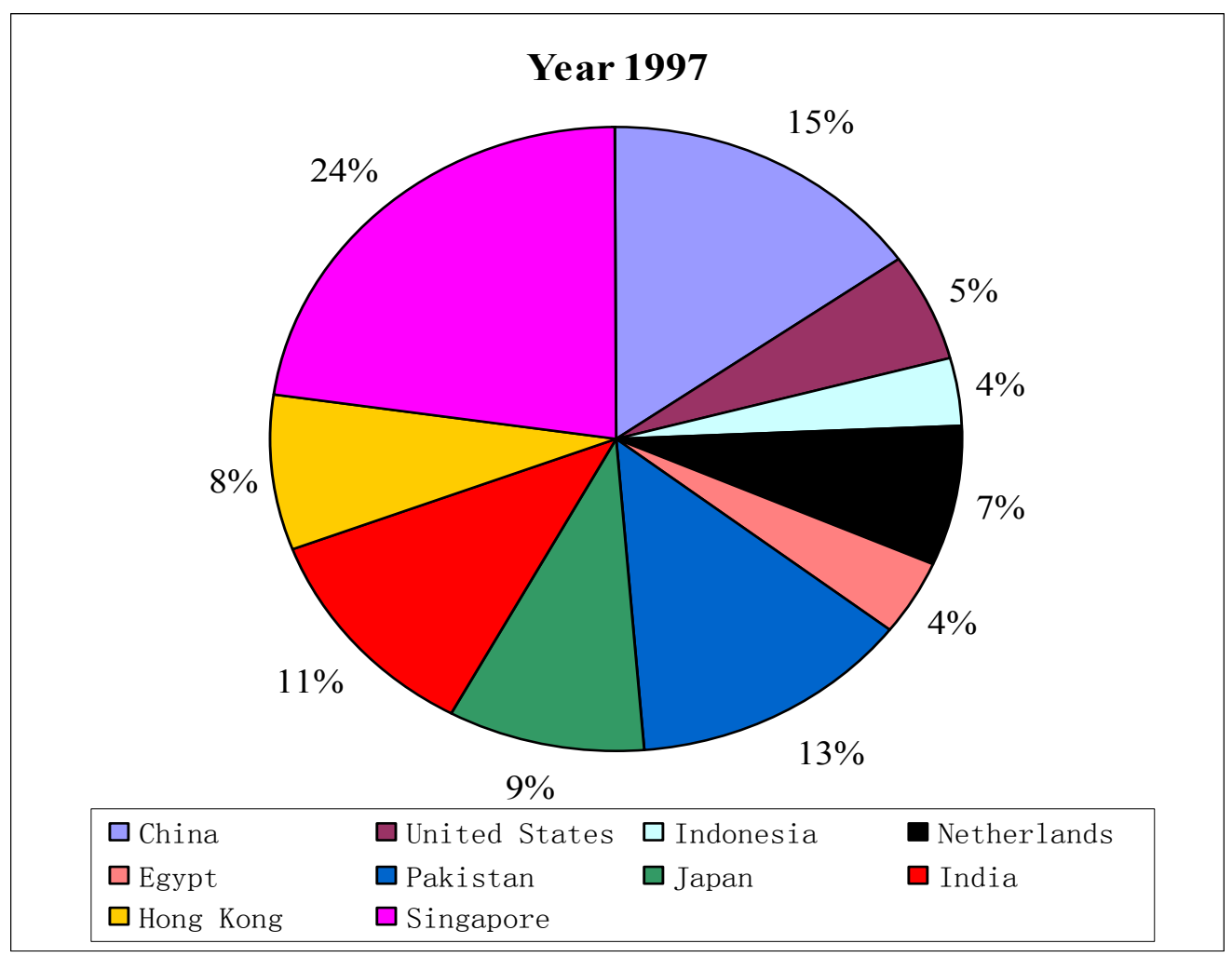

Figure 3. Malaysia's key export markets, 1997 


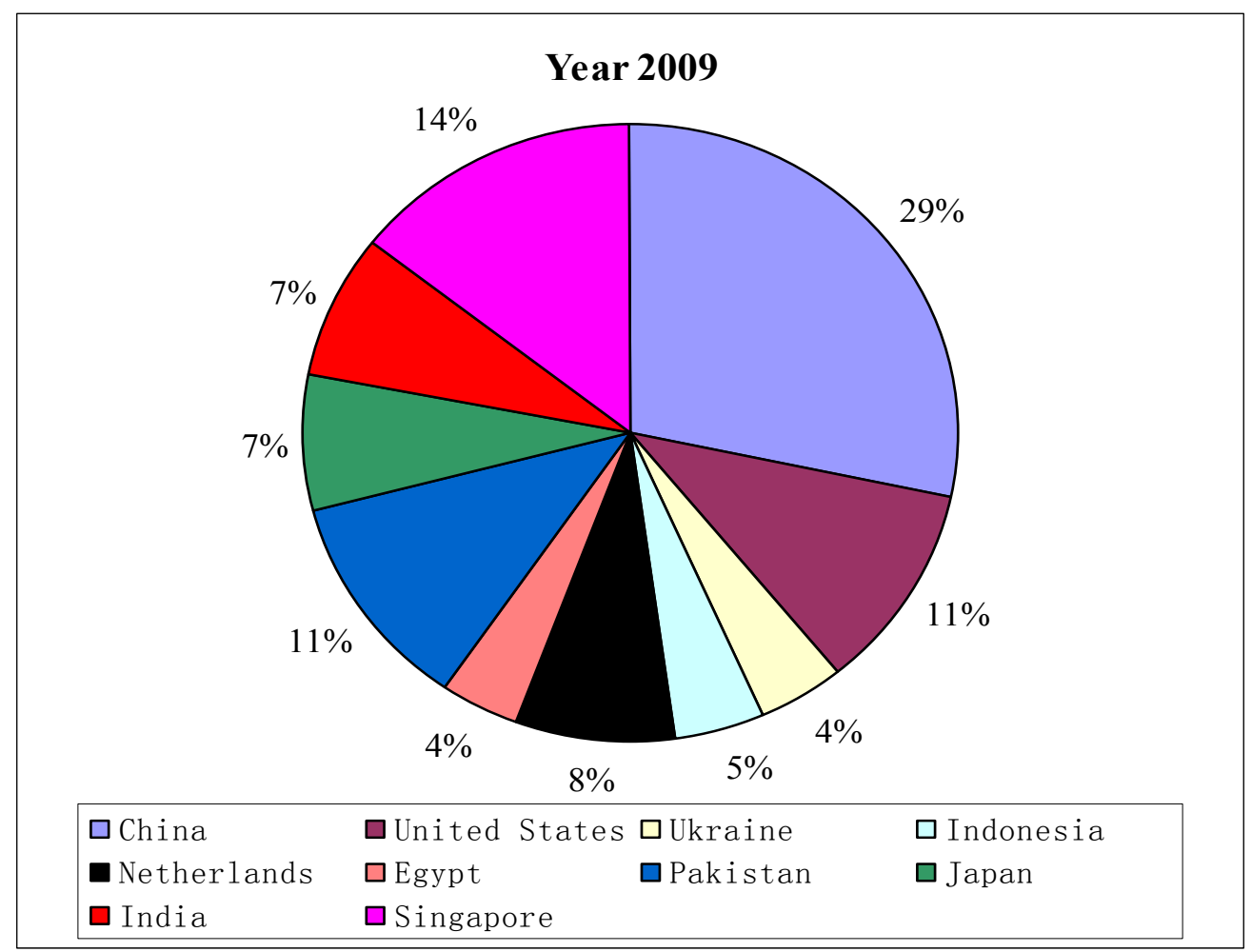

Figure 4. Malaysia’s key export markets, 2009

\subsection{Positive and Negative Net Shift Markets}

Figure 5 shows the top five positive and negative net shift markets in 1997 and 2009. China is the top performer among the Malaysian export markets with the largest positive net shift of RM4.56 billion. It is followed by United States (RM1.92 billion), Ukraine (RM1.44 billion), Benin (RM1.02 billion) and Iran (RM0.2 billion). The positive net shifts markets increased the share of Malaysia's total exports between 1997 and 2009. It is expected to be increasing in the future. The largest contribution to the negative net shift markets is Jordon with the value of -RM3.46 billion. The second largest negative net shift markets is Turkey (-RM2.23 billion), and then followed by India (-RM1.7 billion), Hong Kong (-RM1.22 billion) and Singapore (-RM0.96 billion). The negative net shifts indicate the decreasing share of Malaysia's total exports between 1997 and 2009 to these countries. 


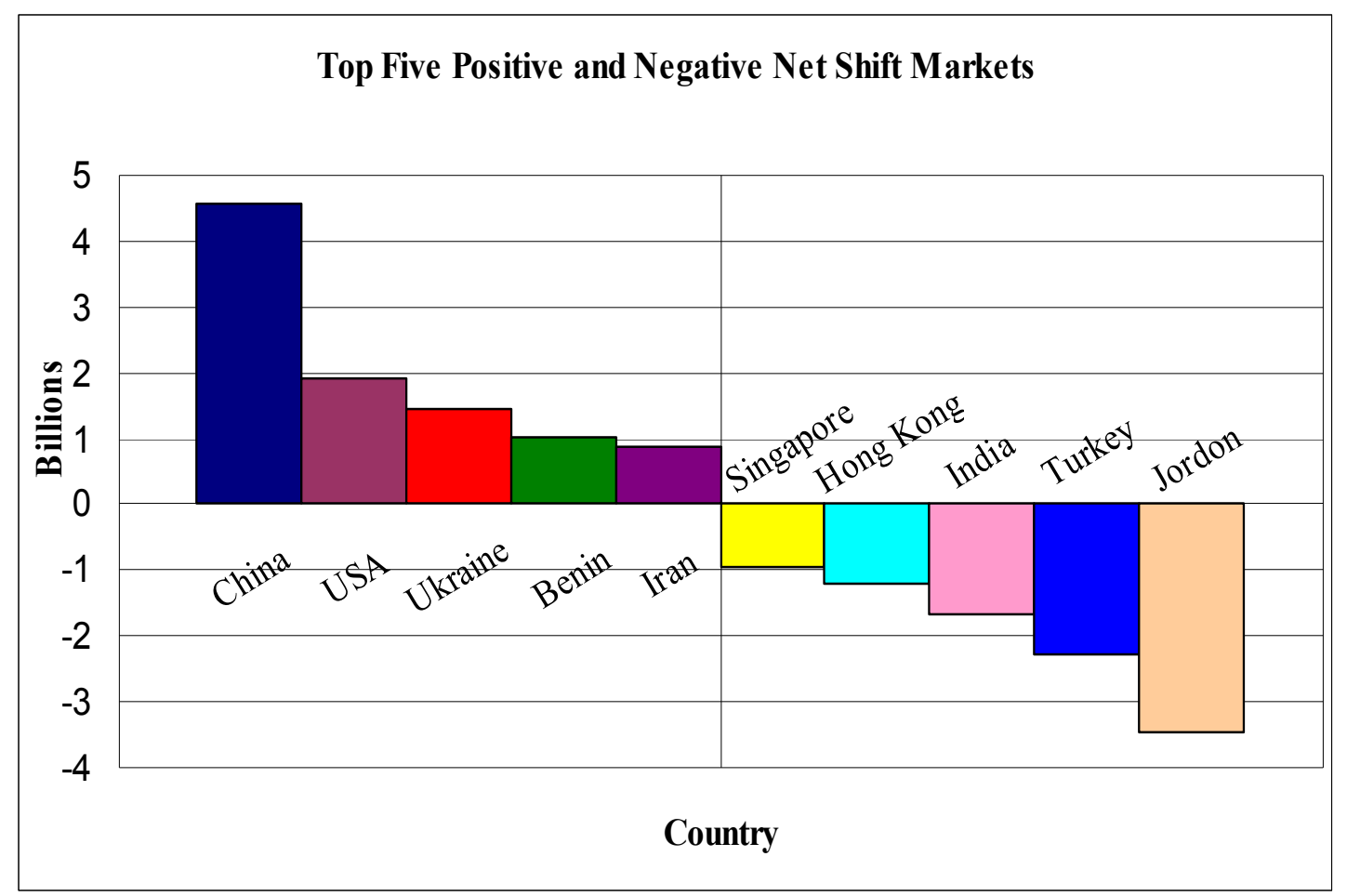

Figure 5. Top five positive and negative net shift markets

\subsection{Export Performance by Commodity Section}

The decomposition of Malaysia's exports by the positive and negative net shifts for the five top countries is shown in Table 2. HS 15 (animal or vegetable fats and oils and their cleavage products; prepared edible fats; animal or vegetable waxes) has a higher percentage of positive net shifts in China, United States, Ukraine, Benin and Iran. It indicates that this commodity experienced rapid growth in all the five positive markets. China became the Malaysia's major trading partner due to the involvement in the bilateral trade and the ASEAN-China Free Trade Agreement (ACFTA). The five largest negative net shifts from Singapore, Hong Kong, India, Turkey and Jordon recorded negative net shifts in HS 15. It led to a decreasing overall export growth in the HS 15. 
Table 2. Decomposition of positive and negative net shifts by country

\begin{tabular}{|c|c|c|c|c|c|c|c|c|c|c|}
\hline \multirow[t]{2}{*}{ HS } & \multicolumn{5}{|c|}{$\%$ Positive Net Shifts } & \multicolumn{5}{|c|}{$\%$ Negative Net Shifts } \\
\hline & China & USA & Ukraine & Benin & Iran & Singapore & Hong Kong & India & Turkey & Jordon \\
\hline 1 & -0.05 & -0.04 & 0.00 & 0.00 & -0.22 & -39.73 & 0.00 & 0.00 & 0.00 & 0.00 \\
\hline 2 & -0.02 & 0.02 & 0.00 & 0.00 & 0.00 & -4.15 & -2.27 & 0.00 & 0.00 & 0.07 \\
\hline 3 & 0.36 & 21.43 & 0.00 & 0.00 & 0.00 & 3.37 & 0.77 & 0.01 & -0.07 & 0.07 \\
\hline 4 & 0.33 & 1.82 & 0.00 & 0.17 & 0.00 & -1.89 & -5.20 & 0.05 & 0.00 & 0.09 \\
\hline 5 & -0.09 & 0.01 & 0.00 & 0.00 & 0.00 & 0.00 & -0.22 & -0.01 & -0.01 & 0.00 \\
\hline 6 & 0.02 & -0.36 & 0.00 & 0.00 & 0.00 & 0.94 & 0.21 & -0.03 & -0.01 & 0.00 \\
\hline 7 & 0.00 & -0.07 & 0.00 & 0.00 & 0.00 & 0.23 & 0.12 & 0.38 & 0.62 & 0.03 \\
\hline 8 & 0.02 & -0.18 & 0.00 & 0.00 & -2.17 & -6.83 & -6.47 & -0.34 & -0.44 & -0.51 \\
\hline 9 & 0.27 & -0.63 & 0.00 & 0.00 & 0.00 & -7.53 & 0.20 & -0.12 & -0.03 & 0.00 \\
\hline 10 & 0.00 & 0.00 & 0.00 & 0.00 & 0.00 & -0.88 & 0.04 & 0.00 & 0.00 & 0.00 \\
\hline 11 & -0.01 & -0.04 & 0.00 & 0.00 & 0.00 & -2.83 & -1.05 & 0.03 & -0.02 & 0.01 \\
\hline 12 & -0.04 & 0.02 & 0.00 & 0.00 & 0.00 & -1.43 & -0.02 & 0.00 & 0.00 & 0.00 \\
\hline 13 & 0.00 & 0.01 & 0.00 & 0.00 & 0.00 & -0.01 & -0.01 & 0.05 & 0.01 & 0.00 \\
\hline 14 & 1.03 & 0.02 & 0.01 & 0.00 & 0.00 & -0.53 & -2.83 & 0.00 & 0.00 & 0.00 \\
\hline 15 & 93.68 & 67.08 & 99.05 & 97.06 & 28.35 & -28.26 & -62.10 & -105.23 & -102.13 & -101.90 \\
\hline 16 & -0.06 & -3.95 & 0.00 & 0.00 & 0.00 & -0.16 & -0.78 & -0.04 & 0.00 & 0.04 \\
\hline 17 & 0.12 & 0.67 & 0.00 & 0.02 & -0.05 & -1.06 & -5.66 & 0.27 & 0.04 & 0.00 \\
\hline 18 & -0.52 & 11.48 & 0.83 & 0.01 & 80.20 & -1.69 & -1.31 & 1.57 & 0.13 & 0.22 \\
\hline 19 & 0.85 & 0.59 & -0.01 & 2.69 & 0.47 & -1.88 & -6.61 & 0.79 & 0.01 & 0.55 \\
\hline 20 & 0.02 & -2.03 & 0.00 & 0.04 & -6.63 & -0.79 & -0.40 & 0.18 & -0.05 & 0.34 \\
\hline 21 & 1.94 & 2.62 & 0.08 & 0.00 & 0.00 & -1.33 & 1.15 & 1.05 & 1.04 & 0.06 \\
\hline 22 & 0.27 & 1.50 & 0.05 & 0.01 & 0.05 & 3.24 & -0.60 & 0.20 & 0.00 & 0.05 \\
\hline 23 & 1.54 & 0.01 & 0.00 & 0.00 & 0.00 & -0.46 & -1.96 & 0.27 & 0.27 & 0.90 \\
\hline 24 & 0.34 & 0.02 & 0.00 & 0.00 & 0.00 & -6.35 & -5.00 & 0.90 & 0.65 & 0.00 \\
\hline Total & 100 & 100 & 100 & 100 & 100 & -100 & -100 & -100 & -100 & -100 \\
\hline Net Shifts (\$ bn) & 4.56 & 1.92 & 1.44 & 1.02 & 0.17 & -3.46 & -2.23 & -1.68 & -1.22 & -0.96 \\
\hline
\end{tabular}

\subsection{Sources of Divergence in Export Market Performance}

Three effects are described by decomposing the net shifts in Malaysia's exports to examine the sources of export divergence in the ten positive and negative markets. The net shifts in exports are determined by adding up the industry mix effect (IME), regional effect (RE) and interaction effect (IE).

Table 3 and 4 summarize the sources of the negative and positive net shifts export markets for the food sector. According to tables 2 and 3, some general information about the exports can be observed on the three components of the net shifts. From the industry mix effects that are obtained from all the ten markets, almost all the ten markets experienced the positive effects except Hong Kong and Singapore. So, Hong Kong and Singapore were recorded as largest negative net shifts markets of Malaysia's total exports.

HS 15 is the only commodity that recorded positive effect in industry mix effect for all the ten Malaysia's export markets. It showed that Malaysia concentrated to export HS 15 commodity. The growth of the HS 15 exports is increasing faster than the other commodities during 1997 to 2009. The interaction effects of the net shifts are usually associated with the regional effects of a similar order of level. When the regional effect is negative, the interaction effect will be positive and vice versa. 
Table 3. Positive net shifts in Malaysia's major export markets (RM mn)

\begin{tabular}{|c|c|c|c|c|c|c|c|c|c|c|c|c|}
\hline \multirow{2}{*}{ HS } & \multicolumn{4}{|c|}{ China } & \multicolumn{4}{|c|}{ USA } & \multicolumn{4}{|c|}{ Ukraine } \\
\hline & Net Shifts & IME & $\mathbf{R E}$ & IE & Net Shifts & IME & $\mathbf{R E}$ & IE & Net Shifts & IME & $\mathbf{R E}$ & IE \\
\hline 1 & -2.1 & -1.6 & -49.1 & 48.5 & -0.7 & -1.0 & 15.0 & -14.6 & 0.0 & 0.0 & 0.1 & -0.1 \\
\hline 2 & -0.8 & -0.8 & 2.0 & -1.9 & 0.4 & 0.0 & 140.2 & -139.7 & 0.0 & 0.0 & 0.1 & -0.1 \\
\hline 3 & 16.4 & -8.0 & 46.5 & -22.0 & 410.6 & -2.7 & 808.4 & -395.1 & 0.0 & 0.0 & -2.8 & 2.8 \\
\hline 4 & 15.1 & -0.1 & $4,970.5$ & $-4,955.3$ & 34.8 & -0.1 & $3,221.1$ & $-3,186.2$ & 0.0 & 0.0 & -0.9 & 0.9 \\
\hline 5 & -4.1 & -3.1 & -1.0 & 0.0 & 0.1 & 0.0 & $482,963.5$ & $-482,963.4$ & 0.0 & 0.0 & 0.0 & 0.0 \\
\hline 6 & 0.7 & 0.3 & 25.1 & -24.7 & -6.9 & 13.4 & -11.9 & -8.4 & 0.0 & 0.0 & -0.5 & 0.5 \\
\hline 7 & -0.1 & 0.1 & -13.4 & 13.2 & -1.3 & 0.4 & -7.6 & 6.0 & 0.0 & 0.0 & -0.5 & 0.5 \\
\hline 8 & 0.8 & -0.5 & 145.5 & -144.2 & -3.5 & -2.4 & -9.1 & 8.0 & 0.0 & 0.0 & -0.1 & 0.1 \\
\hline 9 & 12.3 & -0.2 & $6,045.5$ & $-6,033.0$ & -12.1 & -66.5 & 24.4 & 30.0 & 0.0 & 0.0 & $122,212.5$ & $-122,212.5$ \\
\hline 10 & 0.0 & 0.0 & $20,941.6$ & $-20,941.6$ & 0.1 & 0.0 & $333,011.6$ & $-333,011.5$ & 0.0 & 0.0 & 0.0 & 0.0 \\
\hline 11 & -0.4 & -1.3 & 15.1 & -14.2 & -0.8 & -0.9 & 0.6 & -0.5 & 0.0 & 0.0 & -0.1 & 0.1 \\
\hline 12 & -1.8 & -0.9 & -4.7 & 3.8 & 0.3 & -0.2 & 4.8 & -4.3 & 0.0 & 0.0 & -0.1 & 0.1 \\
\hline 13 & 0.0 & 0.8 & -2.2 & 1.4 & 0.2 & 0.0 & $106,810.5$ & $-106,810.3$ & 0.0 & 0.0 & 0.0 & 0.0 \\
\hline 14 & 46.8 & 0.1 & $2,073.9$ & $-2,027.3$ & 0.3 & 0.3 & 0.0 & 0.0 & 0.1 & 0.0 & $37,212.4$ & $-37,212.4$ \\
\hline 15 & $4,273.8$ & 204.1 & $2,951.4$ & $1,118.4$ & $1,285.1$ & 40.1 & $1,615.0$ & -369.9 & $1,426.0$ & 3.4 & 999.2 & 423.4 \\
\hline 16 & -2.5 & -2.1 & -10.5 & 10.1 & -75.7 & -52.8 & -7.6 & -15.3 & 0.0 & 0.0 & -0.3 & 0.3 \\
\hline 17 & 5.2 & -1.2 & 114.4 & -108.0 & 12.9 & -0.8 & 133.6 & -119.9 & 0.0 & 0.0 & -0.5 & 0.5 \\
\hline 18 & -23.8 & 84.7 & -137.0 & 28.5 & 220.0 & 308.9 & -10.8 & -78.1 & 11.9 & 0.7 & 28.8 & -17.6 \\
\hline 19 & 38.6 & 5.2 & 621.3 & -587.9 & 11.3 & 24.5 & -18.3 & 5.0 & -0.2 & 0.1 & -3.9 & 3.6 \\
\hline 20 & 0.7 & -0.2 & 32.3 & -31.3 & -38.8 & -11.5 & -6.6 & -20.6 & 0.0 & 0.0 & -0.4 & 0.4 \\
\hline 21 & 88.5 & 1.9 & $4,398.2$ & $-4,311.6$ & 50.1 & 13.0 & 99.0 & -61.8 & 1.2 & 0.1 & 18.3 & -17.2 \\
\hline 22 & 12.4 & 1.0 & 751.1 & -739.7 & 28.6 & 6.2 & 86.2 & -63.7 & 0.7 & 0.0 & $2,617,357.2$ & $-2,617,356.5$ \\
\hline 23 & 70.4 & -0.8 & $2,449.9$ & $-2,378.7$ & 0.2 & 0.0 & 70.7 & -70.5 & 0.0 & 0.0 & -0.7 & 0.7 \\
\hline 24 & 15.6 & -11.1 & 136.1 & -109.4 & 0.4 & -0.5 & 37.3 & -36.3 & 0.0 & 0.0 & 68.0 & -68.0 \\
\hline Total & $4,562.0$ & 266.3 & $45,502.6$ & $-41,206.9$ & $1,915.8$ & 267.4 & $928,969.7$ & $-927,321.3$ & $1,439.7$ & 4.3 & $2,777,885.8$ & $-2,776,450.4$ \\
\hline
\end{tabular}


Table 3. Positive net shifts in Malaysia's major export markets (RM mn) (cont'd.)

\begin{tabular}{|c|c|c|c|c|c|c|c|c|}
\hline \multirow{2}{*}{ HS } & \multicolumn{4}{|c|}{ Benin } & \multicolumn{4}{|c|}{ Iran } \\
\hline & Net Shifts & IME & $\mathbf{R E}$ & IE & Net Shifts & IME & $\mathbf{R E}$ & IE \\
\hline 1 & 0.0 & 0.0 & 0.0 & 0.0 & 0.0 & 0.0 & -1.4 & 1.4 \\
\hline 2 & 0.0 & 0.0 & 0.0 & 0.0 & 0.0 & 0.0 & 0.1 & -0.1 \\
\hline 3 & 0.0 & 0.0 & -0.1 & 0.1 & 4.6 & 0.0 & $78,201,622.8$ & $-78,201,618.2$ \\
\hline 4 & 1.8 & 0.0 & $376,650.0$ & $-376,648.2$ & 0.0 & 0.0 & -1.5 & 1.5 \\
\hline 5 & 0.0 & 0.0 & 0.0 & 0.0 & 0.0 & 0.0 & 0.0 & 0.0 \\
\hline 6 & 0.0 & 0.0 & 0.0 & 0.0 & 0.0 & 0.0 & -0.8 & 0.8 \\
\hline 7 & 0.0 & 0.0 & 0.0 & 0.0 & 0.0 & 0.0 & -0.9 & 0.9 \\
\hline 8 & 0.0 & 0.0 & 0.0 & 0.0 & 2.2 & -0.4 & 10.5 & -8.0 \\
\hline 9 & 0.0 & 0.0 & 0.0 & 0.0 & 0.0 & 0.0 & 0.4 & -0.4 \\
\hline 10 & 0.0 & 0.0 & 0.0 & 0.0 & 0.0 & 0.0 & 0.0 & 0.0 \\
\hline 11 & 0.0 & 0.0 & 0.0 & 0.0 & 0.5 & 0.0 & $1,660,604.9$ & $-1,660,604.5$ \\
\hline 12 & 0.0 & 0.0 & 0.0 & 0.0 & 0.0 & 0.0 & -0.2 & 0.2 \\
\hline 13 & 0.0 & 0.0 & 0.0 & 0.0 & 0.0 & 0.0 & -0.1 & 0.1 \\
\hline 14 & 0.0 & 0.0 & 0.0 & 0.0 & 0.0 & 0.0 & -0.4 & 0.4 \\
\hline 15 & 990.3 & 0.1 & 742.2 & 248.0 & 860.1 & 4.6 & 737.3 & 118.2 \\
\hline 16 & 0.0 & 0.0 & 0.0 & 0.0 & 0.2 & 0.0 & $1,239,598.9$ & $-1,239,598.7$ \\
\hline 17 & 0.2 & 0.0 & $28,215.3$ & $-28,215.1$ & 0.1 & 0.0 & 4.9 & -4.8 \\
\hline 18 & 0.1 & 0.0 & $34,946.3$ & $-34,946.2$ & -2.4 & 13.0 & -3.4 & -12.0 \\
\hline 19 & 27.5 & 0.2 & 7.5 & 19.8 & 7.2 & 0.1 & 242.1 & -235.0 \\
\hline 20 & 0.4 & 0.0 & $32,530.6$ & $-32,530.2$ & -2.8 & -1.1 & -0.3 & -1.4 \\
\hline 21 & 0.0 & 0.0 & -0.1 & 0.1 & 13.8 & 0.0 & $105,907,171.2$ & $-105,907,157.4$ \\
\hline 22 & 0.1 & 0.0 & $9,439.3$ & $-9,439.3$ & 0.6 & 0.0 & 111.4 & -110.9 \\
\hline 23 & 0.0 & 0.0 & 0.0 & 0.0 & 5.9 & 0.0 & $50,150,121.6$ & $-50,150,115.7$ \\
\hline 24 & 0.0 & 0.0 & 0.0 & 0.0 & 2.2 & 0.0 & $21,564.7$ & $-21,562.5$ \\
\hline Total & $1,020.3$ & 0.3 & $482,531.0$ & $-481,510.9$ & 892.0 & 16.2 & $237,181,781.8$ & $-237,180,906.0$ \\
\hline
\end{tabular}


Table 4. Negative net shifts in Malaysia's major export markets (RM mn)

\begin{tabular}{|c|c|c|c|c|c|c|c|c|c|c|c|c|}
\hline \multirow{2}{*}{ HS } & \multicolumn{4}{|c|}{ Singapore } & \multicolumn{4}{|c|}{ Hong Kong } & \multicolumn{4}{|c|}{ India } \\
\hline & Net Shifts & IME & $\mathbf{R E}$ & IE & Net Shifts & IME & $\mathbf{R E}$ & IE & Net Shifts & IME & $\mathbf{R E}$ & IE \\
\hline 1 & $-1,374.0$ & $-1,376.5$ & 0.4 & 2.1 & -0.1 & -0.4 & 62.8 & -62.5 & 0.0 & 0.0 & 5.1 & -5.1 \\
\hline 2 & -143.6 & -139.9 & -1.3 & -2.4 & -51.6 & -47.3 & -1.6 & -2.7 & 0.0 & 0.0 & $337,395.8$ & $-337,395.8$ \\
\hline 3 & 116.6 & -15.7 & 190.5 & -58.2 & 17.5 & -14.0 & 18.1 & 13.4 & 0.2 & 0.0 & 856.2 & -855.9 \\
\hline 4 & -65.4 & -124.9 & 18.6 & 41.0 & -117.9 & -34.2 & -34.1 & -49.7 & 0.8 & 0.0 & $233,683,246.3$ & $-233,683,245.5$ \\
\hline 5 & 0.0 & -0.3 & 5.3 & -5.0 & -5.0 & -4.1 & -0.4 & -0.6 & -0.1 & -0.1 & -0.9 & 0.9 \\
\hline 6 & 32.6 & 107.3 & -23.0 & -51.7 & 4.6 & 2.4 & 11.2 & -8.9 & -0.5 & 0.9 & -25.4 & 24.1 \\
\hline 7 & 8.1 & 37.8 & -6.1 & -23.6 & 2.6 & 0.2 & 35.1 & -32.6 & 6.4 & 0.0 & $15,002.9$ & $-14,996.5$ \\
\hline 8 & -236.3 & -246.5 & 3.4 & 6.8 & -146.7 & -114.8 & -8.0 & -23.8 & -5.7 & -4.2 & -14.4 & 12.9 \\
\hline 9 & -260.4 & -223.0 & -21.1 & -16.4 & 4.6 & -5.2 & 84.8 & -75.0 & -2.0 & -1.8 & -8.3 & 8.1 \\
\hline 10 & -30.3 & -28.5 & -0.3 & -1.5 & 0.8 & 0.0 & 727.6 & -726.8 & 0.0 & 0.0 & 2.2 & -2.2 \\
\hline 11 & -97.8 & -80.2 & -7.4 & -10.2 & -23.7 & -23.2 & -0.3 & -0.2 & 0.5 & -0.2 & 67.6 & -66.9 \\
\hline 12 & -49.6 & -21.8 & -9.9 & -17.9 & -0.4 & -0.6 & 1.2 & -0.9 & 0.0 & -0.1 & 5.1 & -5.0 \\
\hline 13 & -0.2 & 6.7 & -3.4 & -3.5 & -0.3 & 2.7 & -1.3 & -1.6 & 0.9 & 0.0 & $1,295,968.4$ & $-1,295,967.5$ \\
\hline 14 & -18.3 & 16.6 & -20.2 & -14.6 & -64.1 & 41.4 & -8.8 & -96.8 & 0.1 & 0.0 & $1,195,072.7$ & $-1,195,072.6$ \\
\hline 15 & -977.4 & 81.1 & $-2,859.7$ & $1,801.1$ & $-1,407.7$ & 54.1 & $-2,115.1$ & 653.4 & $-1,768.9$ & 160.2 & $-1,327.4$ & -601.7 \\
\hline 16 & -5.5 & -67.0 & 67.4 & -5.9 & -17.6 & -23.7 & 6.7 & -0.7 & -0.6 & -0.3 & -36.2 & 35.9 \\
\hline 17 & -36.5 & -54.0 & 10.3 & 7.2 & -128.3 & -49.3 & -18.1 & -60.9 & 4.6 & -0.1 & 576.6 & -571.9 \\
\hline 18 & -58.3 & 122.2 & -233.9 & 53.4 & -29.6 & 24.0 & -126.2 & 72.6 & 26.5 & 7.8 & 190.7 & -172.0 \\
\hline 19 & -64.9 & 312.0 & -172.5 & -204.4 & -149.8 & 180.3 & -93.3 & -236.9 & 13.3 & 1.6 & 532.9 & -521.3 \\
\hline 20 & -27.4 & -27.3 & 0.0 & 0.0 & -9.1 & -5.7 & -2.6 & -0.9 & 3.0 & -0.2 & 102.4 & -99.2 \\
\hline 21 & -46.1 & 478.9 & -159.6 & -365.4 & 26.0 & 65.9 & -31.5 & -8.4 & 17.6 & 0.8 & $1,587.3$ & $-1,570.5$ \\
\hline 22 & 112.2 & 294.1 & -61.5 & -120.4 & -13.5 & 42.9 & -46.7 & -9.7 & 3.3 & 0.2 & 813.5 & -810.4 \\
\hline 23 & -15.8 & -11.7 & -14.4 & 10.4 & -44.4 & -13.4 & -34.5 & 3.5 & 4.6 & -1.2 & 104.0 & -98.3 \\
\hline 24 & -219.6 & -154.4 & -35.3 & -29.9 & -113.3 & -80.6 & -12.1 & -20.6 & 15.1 & 0.0 & $24,503.3$ & $-24,488.1$ \\
\hline Total & $-3,458.1$ & $-1,115.1$ & $-3,333.8$ & 990.9 & $-2,266.9$ & -2.5 & $-1,587.1$ & -677.3 & $-1,681.0$ & 163.3 & $236,554,620.4$ & $-236,556,464.7$ \\
\hline
\end{tabular}


Table 4. Negative net shifts in Malaysia's major export markets (RM mn) (cont'd.)

\begin{tabular}{|c|c|c|c|c|c|c|c|c|}
\hline \multirow{2}{*}{ HS } & \multicolumn{4}{|c|}{ Turkey } & \multicolumn{4}{|c|}{ Jordon } \\
\hline & Net Shifts & IME & RE & IE & Net Shifts & IME & $\mathbf{R E}$ & IE \\
\hline 1 & 0.0 & 0.0 & $2,123,838.5$ & $-2,123,838.5$ & 0.0 & 0.0 & 1.2 & -1.2 \\
\hline 2 & 0.0 & 0.0 & 1.1 & -1.1 & 0.7 & 0.0 & $15,247,256.6$ & $-15,247,255.9$ \\
\hline 3 & -0.9 & -0.1 & -25.4 & 24.6 & 0.7 & 0.0 & 595.6 & -595.0 \\
\hline 4 & 0.0 & 0.0 & -12.6 & 12.6 & 0.9 & 0.0 & $55,906,658.7$ & $-55,906,657.9$ \\
\hline 5 & -0.1 & -0.1 & -0.3 & 0.2 & 0.0 & 0.0 & 0.0 & 0.0 \\
\hline 6 & -0.1 & 0.1 & -7.9 & 7.7 & 0.0 & 0.0 & -5.4 & 5.4 \\
\hline 7 & 7.5 & 0.0 & $202,812,490.1$ & $-202,812,482.5$ & 0.2 & 0.0 & $5,185,331.1$ & $-5,185,330.9$ \\
\hline 8 & -5.4 & -3.9 & -4.5 & 3.1 & -4.9 & -3.9 & -2.4 & 1.4 \\
\hline 9 & -0.4 & -0.4 & -2.9 & 2.9 & 0.0 & 0.0 & 2.3 & -2.3 \\
\hline 10 & 0.0 & 0.0 & 0.1 & -0.1 & 0.0 & 0.0 & 0.1 & -0.1 \\
\hline 11 & -0.2 & -0.1 & -4.6 & 4.5 & 0.1 & 0.0 & $1,956,666.2$ & $-1,956,666.1$ \\
\hline 12 & 0.0 & 0.0 & -1.4 & 1.4 & 0.0 & 0.0 & -1.1 & 1.1 \\
\hline 13 & 0.1 & 0.0 & $66,346.2$ & $-66,346.0$ & 0.0 & 0.0 & -0.5 & 0.5 \\
\hline 14 & 0.0 & 0.0 & -3.8 & 3.8 & 0.0 & 0.0 & -2.4 & 2.4 \\
\hline 15 & $-1,246.6$ & 48.0 & -898.2 & -396.4 & -980.5 & 37.5 & -703.0 & -315.0 \\
\hline 16 & 0.0 & 0.0 & -4.1 & 4.1 & 0.4 & 0.0 & $21,851,041.7$ & $-21,851,041.3$ \\
\hline 17 & 0.5 & 0.0 & $24,530,096.8$ & $-24,530,096.3$ & 0.0 & -0.2 & 3.7 & -3.5 \\
\hline 18 & 1.6 & 6.1 & -17.9 & 13.3 & 2.1 & 1.2 & 12.9 & -12.0 \\
\hline 19 & 0.1 & 0.0 & $10,135,582.4$ & $-10,135,582.3$ & 5.3 & 0.4 & 200.6 & -195.7 \\
\hline 20 & -0.6 & -0.2 & -5.2 & 4.7 & 3.3 & -0.1 & 40.2 & -36.8 \\
\hline 21 & 12.7 & 0.0 & $819,302,183.0$ & $-819,302,170.3$ & 0.5 & 1.6 & -11.4 & 10.4 \\
\hline 22 & 0.0 & 0.0 & $1,307.2$ & $-1,307.2$ & 0.4 & 0.0 & $18,865,870.2$ & $-18,865,869.7$ \\
\hline 23 & 3.3 & 0.0 & $1,402.1$ & $-1,398.7$ & 8.7 & 0.0 & $479,316,887.3$ & $-479,316,878.7$ \\
\hline 24 & 7.9 & 0.0 & $20,576.4$ & $-20,568.5$ & 0.0 & 0.0 & $26,293.4$ & $-26,293.4$ \\
\hline Total & $-1,220.6$ & 49.5 & $1,058,992,835.2$ & $-1,058,994,105.3$ & -962.2 & 36.5 & $598,356,135.7$ & $-598,357,134.4$ \\
\hline
\end{tabular}

\subsection{Sources of Positive Net Shifts in Major Export Markets}

Five positive net shifts markets in Malaysia's total food exports are identified. The following paragraphs discuss the findings by country.

\subsubsection{China}

China was recorded the largest positive net shift with RM4.56 billion in Malaysia's total exports. The encouraging overall regional effect of China made it able to obtain the overall positive industry mix effect. The result shows that HS 15 (animal or vegetable fats and oils and their cleavage products; prepared edible fats; animal or vegetable waxes) is the largest contributor to the positive industry mix and regional effects in Malaysia's exports to China. China stated a significant growth in exports of HS 15 during the period due to the implementation of ASEAN-China Free Trade Agreement (ACTFA) between Malaysia and China. The reduction of tariff up to nine percent boosted the exports of the oils. HS 21 (miscellaneous edible preparations) and HS 23 (residues and waste from the food industries; prepared animal feed) also recorded a significant positive net shifts at RM88.52 million and RM70.40 million respectively. However, among the three commodities, HS 23 experienced a slower growth compared to the total export. It is because of the fact that development of livestock, meat and animal feed industries took place aggressively by the Malaysian government (Stanton et al., 2009).

\subsubsection{United States}

Malaysia recorded the second positive net shift in the exports to the United States with RM1.92 billion. The 
major export commodities to this country are HS 15 (animal or vegetable fats and oils and their cleavage products; prepared edible fats; animal or vegetable waxes), HS 03 (fish and crustaceans, molluscs and other aquatic invertebrates) and HS 18 (cocoa and cocoa preparations). The interaction effect of HS 15 is negative which reflected the lack of concentration in this commodity and the export growth is lower than total export. However, HS 05 (products of animal origin, nesoi) is recorded the largest positive regional effect for United State.

\subsubsection{Ukraine}

Almost 99\% of the Malaysia total export for HS 15 (animal or vegetable fats and oils and their cleavage products; prepared edible fats; animal or vegetable waxes) is to Ukraine. Overall, the three effects in HS 15 showed that the share of Malaysia's export to Ukraine is greater than the Malaysia's total export. The growth for this commodity also follows the same pattern. This indicates that the Eastern Europe is the future market for the oil with the expected growth of more than ten percent (Simon, 2004). This increasing trend is found due to the poor performance of the sunflower oils. So, palm oil is an alternative or substitute for the edible oil. Ukraine also re-export the palm oil to the Central Asian Republic countries and then will increase the Malaysia's export of HS 15 to the country (Malaysian Palm Oil Board, 2010).

\subsubsection{Benin}

Benin experienced the similar case as Ukraine in the HS 15 (animal or vegetable fats and oils and their cleavage products; prepared edible fats; animal or vegetable waxes) and this commodity has the largest share which accounted for about $97 \%$ of Malaysia's total exports to Benin. The three effects in HS 15 also experienced positive situations which indicated that the export growth for this commodity is higher than Malaysia's total exports for HS 15. The regional effect in HS 4 (dairy produce; birds' eggs; natural honey; edible products of animal origin, nesoi) is the largest share among the other Malaysia's exports to Benin. Benin became the hub for palm oil and re-export the products to the western part of Africa since this country stopped to export HS 15 due to the poor performance of the plants and high growth rate of the population (Martin, 2006; Malaysian Palm Oil Council, 2007).

\subsubsection{Iran}

Growth of Malaysia's exports to Iran was dominated by HS 15 (animal or vegetable fats and oils and their cleavage products; prepared edible fats; animal or vegetable waxes) and it has the largest share. All the three effects are positive. United Arab Emirate (UAE) was dominated trade exports and re-exports to Iran, especially in palm oil (Malaysian Palm Oil Fortune, 2009). However, the rising cost of re-exports of palm oil made Malaysia gained the opportunities to export palm oil directly to Iran (Malaysian Palm Oil Fortune, 2009). Due to the declining of shipping freight rates, Iranians eliminated the practices of storing the palm oil in UAE before shipping to the final destination and decided to ship the palm oil directly from Malaysia (Malaysian Palm Oil Fortune, 2009). However, the fastest growing exports were HS 21 (miscellaneous edible preparations) with the largest positive regional effect accompanied by an equal large negative interaction effect of the Malaysia's total exports. The Malaysia's exports of HS 21 to Iran grew fastest among the five positive net shift markets. However, HS 21 was also categorized as the lowest concentration in Iran market than in all other markets.

\subsection{Sources of Negative Net Shifts in Major Export Markets}

Five negative net shifts markets in Malaysia's total food exports are identified. Following sections discuss the finding by the country.

\subsubsection{Singapore}

Malaysia recorded the largest negative net shift in the exports to Singapore. The exports to Singapore was found to decrease from the largest share of the total Malaysia's exports in 1997 to the second largest share in 2009 which was after China. Almost all the HS commodities were recorded in negative net shifts except HS 03 (fish and crustaceans, molluscs and other aquatic invertebrates), HS 05 (products of animal origin, nesoi), HS 6 (live trees and other plants; bulbs, roots and the like; cut flowers and ornamental foliage), HS 07 (edible vegetables and certain roots and tubers) and HS 22 (beverages, spirits and vinegar) with a small share. The largest share among these commodities was HS 22 with RM116 million. HS 01 (live animals) was recorded the largest net negative shifts among the all commodities of the Malaysia's total exports to Singapore. However, the regional and interaction effect of HS 01 were positive which means that the growth rate in HS 01 exports to Singapore was higher than the Malaysia's overall export growth. Besides, it also showed that Malaysia's HS 01 exports to Singapore were higher than Malaysia's total HS 01 exports. The dramatically decreasing nature of the exports of HS 01 was due to the meat and poultry import regulation in Singapore. Singapore just allowed the countries 
which signed the protocol agreements with them to exports the meat and poultry to Singapore to ensure the food safety with the union of foreign farms certification, inspection and regular testing (Trade Chakra, 2008).

\subsubsection{Hong Kong}

Hong Kong experienced smaller overall negative net shifts than to Singapore with RM2267 million. Hong Kong experienced almost the similar situation as Singapore. Almost all the commodities were recorded negative except HS 03 (fish and crustaceans, molluscs and other aquatic invertebrates), HS 06 (live trees and other plants; bulbs, roots and the like; cut flowers and ornamental foliage), HS 07 (edible vegetables and certain roots and tubers), HS 09 (coffee, tea, mate and spices), HS 10 (cereals) and HS 21 (miscellaneous edible preparations) with a smaller share recorded compared with Singapore. HS 21 was the highest positive net shifts with amount of RM 26 million. Among the commodities, HS 15 (animal or vegetable fats and oils and their cleavage products; prepared edible fats; animal or vegetable waxes) was the largest negative net shifts. According to HKDTC in 2009, Hong Kong's trade with ASEAN shrank by $12 \%$ year-on-year with exports and imports declined by $17 \%$. Malaysia as one of the members of ASEAN also could not avoid from the deficit of exports to Hong Kong. The reason may be due to the focusing on regionalism trading of ASEAN in Malaysia. Besides, Malaysia shifted the exports to the countries which have the larger market share of edible oil in the world such as India and China. Furthermore, Malaysia tend to export more HS 15 to the Middle-East and Sub-Saharan countries like Iran and Benin. All these reasons may result in the negative net shifts of Malaysia's total exports to Hong Kong, especially in HS 15.

\subsubsection{India}

Growth of Malaysia's exports to India decreased dramatically by the poor performance of HS 15 (animal or vegetable fats and oils and their cleavage products; prepared edible fats; animal or vegetable waxes) exports with the negative export value at RM1,769 million. However, the total negative net shifts in India was RM1,681 million. According to the record, export of HS 15 to India has increased between 1997 and 2009. The negative net shifts occurred due to the slow growth rate of HS 15 in India compared to other countries. One of the factors why the scenarios such as this happen is the trade liberalization policy imposed by the Indian government (United States, Department of Agriculture, 2006). Before the liberalization, the oil imports quantity was determined by government (Rifin, 2010) and after the policy effectives, the oil imports was controlled by imposes of tariffs. However, the import duties reduced since the demand for crude edible oil increased due to the deficit of oil seed in India which results in the shortage in edible oil. So, the HS 15 exports to India are expected to increase in the future. Besides, the other commodities that have negative values were just in small scale. HS 04 (dairy produce; birds' eggs; natural honey; edible products of animal origin, nesoi) was the commodity recorded the largest positive regional effect with an equal large negative interaction effect among the ten major positive and negative net shifts markets. It showed the HS 04 export to India grew much faster than the other markets while the lower concentration of HS 04 in India than in all other markets.

\subsubsection{Turkey}

Turkey also experienced the similar situation as India in the HS 15. The negative net shifts in HS 15 (RM1,247 million) was greater than the total Turkey's net shifts (RM1,221 million). However, Turkey has a large share of the overall regional effect. The positive regional effect occurred since exports of several of commodities to Turkey grew with a higher rate than the Malaysia's overall export growth. Reduction of exports in palm oil is due to its hiked price and then the country has chosen soybean oil as a substitute of the palm oil. Besides, the Turkish government imposed the import quotas of oil which affected the Malaysia's exports to Turkey (Malaysian Palm Oil Council, 2010). This is the factor behind the dramatic reduction of the HS 15 exports to Turkey.

\subsubsection{Jordon}

Jordon was the fifth largest negative markets of the Malaysia's total exports. Jordan faces the same experience as India and Turkey where the HS 15 (RM981 million) exports is decreased and the negative net shifts is greater than Malaysia's total exports to Jordon (RM962 million). In fact, the exports of palm oil to Jordan were decreasing from 1997 to 2007. It increased again in 2008 because of the re-exports of palm oil to its neighbouring countries such as Iraq and Syria (Malaysian Palm Oil Board, 2009). However, the dramatically decrease was recorded in 2009 mainly due to the reduction of re-exports to neighbouring countries which preferred to import palm oil directly from Malaysia. It was because of increasing re-export cost from Jordan and the reduction of the shipping freight rate (Malaysian Palm Oil Board, 2010). 


\section{Conclusion}

This paper examined the trends in Malaysia's export food market growth from 1996 to 2009 using shift-share analysis. The increase in exports was greater than Malaysia's overall export growth rate experienced the positive net shifts in exports and vice versa. The results indicate that the largest positive net shifts markets are China, United States, Ukraine, Benin and Iran while Singapore, Hong Kong, India, Turkey and Jordan are identified as the largest negative net shifts markets. Then, the decomposition of net shifts in regional effect (RE), industry mix effect (IME) and interaction effect (IE) are further analysed. HS 15 (animal or vegetable fats and oils and their cleavage products; prepared edible fats; animal or vegetable waxes) is the largest Malaysia's total exports and its' share has increased from $68 \%$ in 1997 to $72 \%$ in 2009 . This increasing trend occurred due to increasing demand for cheaper and affordable crude edible oil in the Eastern Europe, Middle-East and Eastern Asia countries especially China. The exports of cocoa commodities (HS 18) also show a significant increasing trend in Malaysia's total exports and the quantity and export value also have increased (Malaysian Cocoa Board, 2010). It showed that the world consumption of cocoa has been increasing. Cocoa consumption is estimated to have increased to 2.23 million tonnes and grew steadily well above three million tonnes by 2008 (Bernama, 2006). So, there is still a lot of growing space for further expansion in the global demand for cocoa-based products. It is very important for Malaysia to further expand the global market via the establishment of market linkages with the FTAs partners.

In the years ago, Malaysia has been implementing regional trade agreements (RTAs) with ASEAN Free Trade Agreement (AFTA) which requires removing the trade barriers between the partner countries within ASEAN. However, the agreement is still not yet being fully implemented due to the Sensitive and Highly Sensitive Unprocessed Agricultural Products such as unprocessed agriculture products, tobacco products, plywood, ceramics and glass, iron and steel and automotive products. All the ASEAN countries will remove barriers gradually from year to year to achieve the totally free trade zone in this region. ASEAN could recover very fast from the financial crisis due to the powerful relationship in the region. However, Singapore, which is one of the AFTA members, recorded as the largest negative net shifts in the export of Malaysia. Singapore is practicing the multilateralism beside regionalism because they believed that the RTAs would direct to trade diversion and decrease the overall growth from international trade. So, they used multilateralism as buffer in order to reduce the incentive of countries. This is the reason why the share of the Malaysia's export to Singapore reduced dramatically. However, the volume of export was still remain as Malaysia's major key export markets with the second position after China.

Besides the region of ASEAN countries, the ASEAN-China Free Trade Agreement (ACFTA) is also an important factor in the contribution of the Malaysia's exports as it will strengthen the intra-regional trade. It is established in the findings that China is the largest and fast growing Malaysia's exports market. With ACFTA, ASEAN and China create an economic region with the total of 1.7 billion consumers. For Malaysia, it is able to access the largest market in the world with 1.2 billion populations.

\section{Policy Implications and Recommendation}

From the analysis, Malaysia has competitive advantage in edible oil. This commodity has been exported to the world markets and the demand for it has been increased from newly industrialized country. To maintain its competitiveness level, the government made high investment in research and development both in oil palm cultivation and production. However, there is an argument that oil palm cultivation will destroy ecosystem of the tropical forest. So, the anti-palm oil campaign was established. Even there is anti-palm oil campaign, the exports for edible oil still increasing due to shortage in other edible oils such as sunflower oils and the price is low and can be afforded by most of the populations in the world. Palm oil is one of the vital industries for Malaysia in the future. To sustain, increasing palm oil productivity is important instead of expanding new areas for plantation. Yield improvement from the existing area, efforts to find ways and means to reduce the production cost and to be more environmental friendly are effective policy for the sustenance of palm oil production.

Malaysia faces the strong competition from the Asian region to export its commodities to the highly industrialized countries, especially China. China has the largest population in the world, so she is able to supply the low-wage labour in their production. It is China's competitive advantage that can export in the whole world with the lowest cost. However, the other costs like transaction cost that remain high give Malaysia some breathing space. Beside the small negative impact from the fast growth of China, it is the largest trading partner to Malaysia able to take advantage to export to the largest population country in the world. This helps Malaysia to improve the exports and achieve the favourable economic growth in recent decades. The future growth is expected to increase with the impact of the bilateral trading between Malaysia and China. 
The increasing of important market in China, Eastern Europe and Middle-East countries as recorded the positive net shifts in these regions. Besides, Malaysia penetrated into Sub-Saharan region such as Benin which experienced significant positive net shifts. It indicates that Malaysia will continue to explore more potential countries in these regions in order to gain the advantage. India is also a potential market for exports to Malaysia although the negative net shifts were identified. The slow growth of edible oil industry in India compared to the other countries is going to grow rapidly in the future. In order to boost Malaysia's exports performance, the trading opportunities of new markets in these regions has to be identified.

Malaysia focuses in the region economic instead of multilateralism. AFTA boosts the trading performance in this region help ASEAN region to grow well. Trade between Malaysia and ASEAN countries is significant. Furthermore, the link between APEC and AFTA will make the trade improve significantly. The regional agreements which emphasized in the reduction of the tariff in agricultural industries will benefit Malaysia since it is recognized as Malaysian economic engine. The different comparative advantage in this region can help Malaysia attract foreign direct investment as well as make the whole region to be strong in own commodities.

As Malaysia's food exports highly depend on edible oils, it will have a strong impact on the economy if the edible oil production decreases. So, Malaysia has to improve its competitive advantage in other commodities besides edible oil. The cocoa product is potential commodity to boost the export performance. Improvement in the export of cocoa products instead of being highly dependent on just a single product/sector is very important for the further growth in economic for Malaysia. In fact, the increase of cocoa exports can be identified as an increasing consumption trend in the world. The trend is significantly increasing in developed countries, especially Europe which is continuing to be the largest consuming country in cocoa (Food and Agriculture Organization of the United Nations, 2003). Malaysia as the largest exporter of cocoa in Asia should improve the cocoa production in order to export to Europe with the high quality cocoa.

Besides, diversification of the export markets is also very important to Malaysia. The food exports trend in Malaysia is no longer aligned with Malaysia's traditional export markets. Malaysia finds its own way to expand the markets to the developing countries which are experiencing a fast growth rate with high demand to the exports. These potential markets with its large population will boost Malaysia's exports. So, Malaysia should identify the potential markets especially in the developing countries in order to diversify Malaysia's exports with the penetration strategy.

Free trade agreements (FTAs) proved to be one of the best ways to open up the foreign markets for Malaysian exporters. Malaysia has a lot of bilateral agreements with various countries. Malaysia has concluded bilateral FTAs with Japan, Pakistan and New Zealand, negotiating the agreements with Chile, India and Australia, and regional FTAs with China, South Korea, Japan, India and Australia-New Zealand (Abdul Rahmat Mamat, 2009). The agreements enable Malaysia to penetrate the partner countries more easily with the removal of entry barriers. Exporters will enjoy the cost savings from elimination or reduction of the customs duties and the regulations of exports. So, Malaysia should fully take advantage of FTAs to further deepen trade with partner countries. The benefits from FTAs are to be realized, but the argument is still non-stop of the increasing of competition. Some exporters found that they have to work harder and more efficient to compete. It is an acceptable challenge that exporters have to face in the short term instead of want to gain more in the long term. To gain more benefits from these agreements, Malaysia government should maintain the good partner relationship between the countries to explore more opportunities to expand the market access and boost the business opportunities for exporters in the new and emerging markets such as Middle-East. The potential partners should not be underestimated, but Malaysia has to be aggressive to increase the exports to these potential newly emerging countries which enable us to gain the win-win situations in the international markets (Abdul Rahmat Mamat, 2009).

\section{References}

Armstrong, H. W., \& Taylor, J. (1978). Regional Economic Policy and Its Analysis. Philip Alland Ltd, Oxford.

Castaldi, C. (2009). The Relative Weight of Manufacturing and Services in Europe: An Innovation Perspective. $\begin{array}{lllll}\text { Technological Forecasting } & \text { 709-722. }\end{array}$ http://dx.doi.org/10.1016/j.techfore.2008.08.001

Cocoa Exports to Reach RM2 Billion by End-2005. (2006, January 16). Bernama.

Edmund, W. L. (2007). Animal and Vegetable Fats, Oils and Waxes. Kent and Riegel's Handbook of Industrial Chemistry and Biotechnology, 2, 1549-1656.

Food and Agriculture Organization of the United Nations. (2003). Medium-Term Prospects for Agricultural Commodities: Projections to the year 2010. Rome. Retrieved October 8, 2010, from http://www.fao.org 
Fothergill, S., \& Gudgin, G. (1979). In Defence of Shift-Share Analysis. Regional and Urban Economics, 12, 249-255.

Global Trade Atlas. (2010). Global Trade Information Service, Inc. Retrieved June 20, 2010, from http://www.gtis.com/gta

Hoover, E. (1971). An Introduction to Regional Economics. Alfred A. Knopf, Inc., New York.

Ibrahim, A. (2008, March 12). The Alternatives for Tobacco Farmers: Many Tobacco Companies have Lost Millions in Major Legal Settlements. New Straits Time.

Kian, H. P., \& Fot, C. W. (1999). Growth in Singapore's Export Markets, 1990-1996: A Shift-Share Analysis. Asian Economic Journal, 13, 3.

Malaysia Palm Oil Council. (2010). Turkey's Crop prospect Improving.

Malaysian Palm Oil Board. (2010a). Overview of the Malaysian Oil Palm Industry 2008. Retrieved October 3, 2010, from http://econ.mpob.gov.my/economy/Overview_2008.pdf

Malaysian Palm Oil Board. (2010b). Overview of the Malaysian Oil Palm Industry 2009. Retrieved October 3, 2010, from http://econ.mpob.gov.my/economy/Overview_2009.pdf

Malaysian Palm Oil Council (MPOC). (2007). Pakistan-Malaysia FTA Signed. Malaysian Palm Oil Fortune, 12.

Malaysian Palm Oil Fortune. (2009). Iran: Biggest Importer of Malaysian Palm Oil West of Asia. Retrieved October 3, 2010, from http://www.americanpalmoil.com

Malaysian-German Chamber of Commerce and Industry. (2010). Market Watch Malaysia 2010-Food Industry.

Mamat, A. R. (2009, December 7). Should Malaysia Pursue Free Trade Agreements? The Star.

Martin, S. (2006). An Edible Oil for the World: Malaysian and Indonesian Competition in the Palm Oil Trade, 1945-2000. In A. J. H. Latham, \& H. Kawakatsu (Eds.), Intra-Asian Trade and the World Market (pp. 209-229). Routledge, London.

Rifin, A. (2010). Export Competitiveness of Indonesia's Palm Oil Product. Trends in Agriculture Economic, 3(1), 1-18. http://dx.doi.org/10.3923/tae.2010.1.18

Simeh, M. A., \& Kamarudin, M. F. (2009). An Overview of Malaysian Palm Oil Market Share in Selected Markets. Oil Palm Industry Economic Journal, 9(1).

Simon, P. (2004). Malaysian Palm Oil Focuses on Eastern Europe. Retrieved September 30, 2010, from http://www.foodnavigator.com

Stanton, Emms and Sia. (2006). The ASEAN Free Trade Area and Its Future Impact on Food Business and Marketing Strategy in South East Asia - 2006 to 2011.

Stanton, Emms and Sia. (2009). Characteristics of Malaysia's Animal Feed Market. Agriculture and Agri-Food Canada.

Stevens, B. H., \& Moore, C. L. (1980). A Critical Review of the Literature on Shift-Share as a Forecasting $\begin{array}{lllll}\text { Technique. } & \text { Journal } & \text { Regional } & \text { Science, } & \text { 20(4), }\end{array}$ http://dx.doi.org/10.1111/j.1467-9787.1980.tb00660.x

Trade Chakra. (2008). Singapore Imports. Retrieved September 8, 2010, from http://www.tradechakra.com

Wali, I. M. (2009). An Analysis of the Industrial Development Potential of Malaysia: A Shift-Share Approach. Journal of Business \& Economics Research, 7(5).

Wiig, A., \& Kolstad, I. (2005). Lowering Barriers to Agricultural Exports through Technical Assistance. Food Policy, Elsevier, 30(2), 185-204. http://dx.doi.org/10.1016/j.foodpol.2005.04.003

Wilson, P., \& Chern, T. S. (2005). A Dynamic Shift Share Analysis of the Electronics Export Market 1988-2001: Can the NIEs Compete with China? Department of Economics, SCAPE Working Paper Series, Paper No. 2005/07-May2005. Retrieved from http://nt2.fas.nus.edu.sg/es/pub/wp-scape/0507.pdf

\section{Copyrights}

Copyright for this article is retained by the author(s), with first publication rights granted to the journal.

This is an open-access article distributed under the terms and conditions of the Creative Commons Attribution license (http://creativecommons.org/licenses/by/3.0/). 